\title{
BCL2L1 wt Allele
}

National Cancer Institute

\section{Source}

National Cancer Institute. BCL2L1 wt Allele. NCI Thesaurus. Code C49420.

Human BCL2L1 wild-type allele is located in the vicinity of 20q11.1 and is approximately 1 $\mathrm{kb}$ in length. This allele, which encodes apoptosis regulator $\mathrm{Bcl}-\mathrm{X}$ protein, is involved in apoptotic regulation. 